\title{
PERIODISMO DEPORTIVO. El Fútbol es el Rey
}

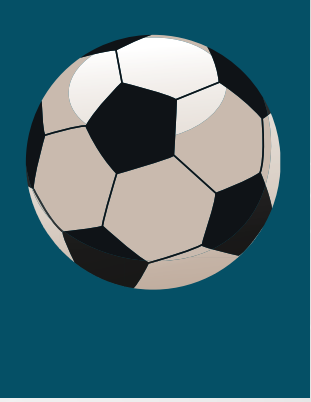

Lizandro Ángulo Rincón* Antonia Moreno Cano**

Recibido. Septiembre 5, 2016 - Aceptado. Octubre 3, 2016

RESUMEN: En el artículo se presenta los resultados del análisis de contenido realizado a la sección de deportes del periódico El Espectador. Se estudiaron seis semanas compuestas correspondientes a dos años de publicación del diario. Se encuentra que el fútbol, el tenis y el automovilismo son los deportes más mencionados en este diario, también que en este tipo de noticias se requiere variedad temática y pluralidad de fuentes.

El Espectador realiza un periodismo "serio", con vocación informativa, que se ve reflejado en sus piezas periodísticas. El calificativo de serio se refiere a que en los contenidos deportivos suele primar la información del desempeño atlético y competitivo, y no los aspectos extradeportivos relacionados con la vida personal y financiera de deportistas, exdeportistas, técnicos, dirigentes, entre otros personajes, como suele ser la tendencia en el periodismo deportivo, inclusive de diarios generalistas en algunos países del mundo.

En las observaciones a las piezas analizadas, tampoco se encuentra el abuso del lenguaje bélico, errores gramaticales, impropiedades léxicas ni la evaluación minuciosa de aspectos intranscendentes de la actividad agonística (competitiva) que suelen publicarse en otros medios. No obstante, se echa de menos un periodismo deportivo más investigativo, de denuncia que permita indagar a fondo sobre las situaciones "desviadas" del deporte (corrupción, apuestas, dopaje, malos manejos administrativos de federaciones). El trabajo en equipo con otras secciones es fundamental en estos casos.

Palabras clave: periodismo, deportes, información, Colombia, análisis cuantitativo, El Espectador, fútbol.

*Doctor en Comunicación, profesor asociado de la Universidad del Tolima.email: langulo@ut.edu.co

${ }^{* *}$ Doctora en Comunicación, asesora de investigaciones
de la Universidad Manuela Beltrán, sede Bucaramanga.
email: antonia.moreno@docentes.umb.edu.co




\section{SPORTS JOURNALISM. Soccer is king}

SUMMARY: This article presents the results of a content analysis carried out with the sports section of the "EL Espectador" newspaper. Six composed weeks, corresponding to 2 years of publication, were studied. It was found that Soccer, Tennis, and Auto Racing are the sports that get the most mentions in the newspaper; also, that this kind of news requires theme variety and sources diversity.

"El Espectador" offers a 'serious' journalism with informative vocation, which is evidenced in its journalistic pieces. The adjective 'serious' refers to the fact that in the sports content the information regarding athletic and competitive performance is prevalent, in contrast with the irrelevant information regarding the private and financial life of athletes, former athletes, coaches, and managers among others, which is a tendency in sports journalism, even in general newspapers in some countries. Abuse of warlike language, grammar errors or lexical inappropriateness were not found in the pieces analyzed, neither was the exhaustive evaluation of unimportant aspects of the competitive activity commonly published in other media.

Nevertheless, the newspaper lacks a more investigative sort of sports journalism that could allow inquiring deep into situations deviated from sports (corruption, bets, doping, and federations mismanagements). Team work with other sections is fundamental in such cases.

Keywords: journalism, sports, information, Colombia, quantitative analysis, El Espectador, football.

\section{JORNALISMO ESPORTIVO. O Futebol é o Rei}

RESUMO: No artigo se apresenta os resultados da análise do conteúdo levados a cabo pela seção de esportes do jornal O Espectador. Se estudaram seis semanas compostas que correspondem a dois anos de publicação do jornal. É achado que o futebol, o tênis e o automobilismo são os esportes mais mencionado neste jornal, também que neste tipo de notícias é requerido variedade temática e pluralidade de fontes.

O Espectador realiza um jornalismo "sério", com vocação informativa que é refletida nos pedaços jornalísticos dele. O epíteto de sério se refere que nos conteúdos desportivos prevalece normalmente a informação da ação atlética e competitiva, e não o aspectos extradeportivos relacionados com a vida pessoal e financeira de desportistas, exdeportistas, técnicos, líderes, entre outras personagens, como isto normalmente é a tendência no jornalismo desportivo, inclusivo de diários generalistas em alguns países do mundo.

Nas observações para os pedaços analisados. também não se acha o abuso da linguagem bélica, erros gramaticais, impropriedades léxicas nem a avaliação meticulosa de aspectos intranscendentes da atividade agonística (competitiva) que normalmente se publicam em outros meios. Não obstante, se sente saudades por um jornalismo esportivo, mas investigativo de denúncia, que permita investigar a fundo nas situações "desviadas" do esporte (corrupção, apostas, dopaje, manipulações administrativas ruins de federações). O trabalho em time com outras seções é fundamental nestes casos.

Palavras chaves: jornalismo, jogo esportivos, informação, Colômbia, análise quantitativa, El Espectador, futebol 


\section{INTRODUCCIÓN}

os estudios de la comunicación y el periodismo en el mundo occidental cuentan con diversas y enriquecedoras perspectivas metodológicas y de análisis. En el ámbito periodístico los investigadores han centrado su particular interés en la manera como se desarrolla el periodismo político, de orden público, cultural y económico. Sin embargo, los comunicólogos y otros profesionales de las ciencias sociales han mostrado poca preocupación por la forma como se ejerce el periodismo deportivo, pese a que su producción noticiosa es ampliamente demandada por la sociedad. Es probable que, en el imaginario académico, las informaciones sobre el deporte se vislumbren en espacios propios de lo trivial y lo pasional.

Esta percepción puede reñir con el significado social que el deporte tiene en millones de personas que lo consumen a través de los medios de comunicación. En Colombia, nunca antes se había visto un seguimiento sostenido de sus deportistas en diferentes disciplinas en la prensa escrita, la radio, la televisión e internet. Ese alto consumo coincide con los éxitos de sus atletas en las olimpiadas de Londres 2012, en las que el país consiguió su mejor figuración de la historia con 1 medalla de oro, 3 de plata y 4 de bronce. No obstante, estas victorias han sido más notorias en los Juegos Panamericanos y Parapanamericanos, puesto que los deportistas colombianos han ganado medallas de oro de una forma progresiva, lo cual les ha permitido superar a Venezuela, Argentina y a México en el cuadro de galardonados (Comité Olímpico Colombiano, 2015).

El interés creciente de la audiencia por el deporte en el panorama nacional e internacional nos llevó a investigar si el periodismo deportivo seguía centrado en deportes hegemónicos y mayoritarios como el fútbol que cuentan con un fuerte y sostenido respaldo publicitario y mercantil, también nos preguntamos por la calidad de la información desde criterios como titulación, fuentes, variedad temática, entre otros. El estudio se enfocó al periódico EI Espectador, diario de cobertura nacional con más de 128 años de funcionamiento, se analizaron dos años de sus piezas periodísticas, utilizando una muestra aleatoria de semanas compuestas.

\section{Periodismo deportivo}

Hoy, seguramente, no se vería con buenos ojos que un medio de comunicación generalista no tuviera una sección deportiva. De hecho, como lo sugieren Billings y sus colegas (2012, págs. 1-5), la vida misma sería distinta si no existieran los deportes, y es que la actividad competitiva, física, recreativa, es una faceta clave para el devenir humano porque gusta, educa, entretiene, fomenta los valores como la disciplina, la perseverancia y estimula la economía. La comunicación juega un rol relevante en la comprensión del deporte como fenómeno orbital, puesto que los profesionales del periodismo son los encargados de convertirlo en un producto de fácil acceso a la población.

Para Boyle (2006, págs. 3-5) tres factores influyen para que los deportes tengan la relevancia mediática de estos tiempos: la globalización, porque el deporte configura identidades locales y globales, muchas de las cuales sirven para expresar tensiones y conflictos; la digitalización, puesto que dentro de la especialidad del periodismo deportivo se ha visto la aparición de una cada vez más sofisticada batalla por el control de los deportes y de cómo ellos son transmitidos y apropiados por la audiencia; y la mercantilización, ya que ésta ha impactado a la vez a los deportes y las industrias de medios, es decir, la industria deportiva ahora y en forma regular involucra más medios e instituciones financieras, así como a las agencias gubernamentales.

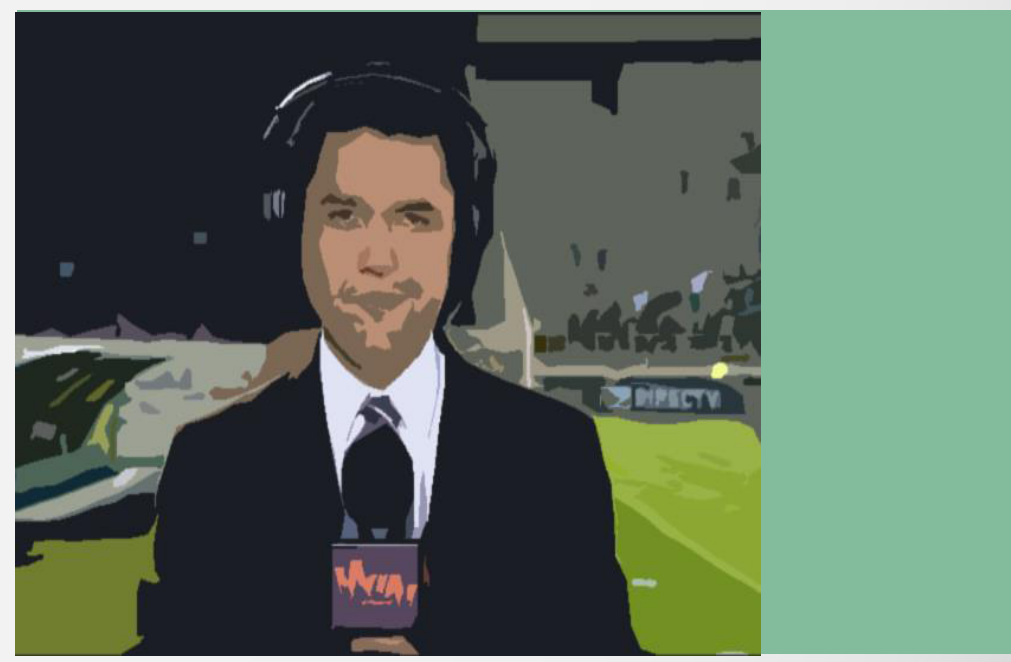

En ese contexto, el periodismo deportivo es una especialidad periodística de paradojas. Por una parte, ha sido y es la sección de la prensa cuya audiencia aumenta, es decir, sus contenidos son cada vez más demandados por lectores, oyentes, televidentes y cibernautas en el mundo y, al mismo tiempo, los que más atraen el patrocinio de diversas marcas. Por otra, es una especialidad a la que se le cuestiona su calidad, pues el periodista dedicado a comunicar e informar sobre deportes se concibe 
como un profesional superficial, apasionado y con poco deseo de respetar las normas idiomáticas y la ética fundada en la veracidad, la confrontación de las fuentes, la separación entre la información y la opinión, la independencia y la responsabilidad social. Estos son algunas de sus falencias, sin embargo, hay que resaltar sus fortalezas. Una de ellas su capacidad para llegar a todo tipo de públicos, a pesar de la gran cantidad de expresiones técnicas de cada disciplina deportiva.

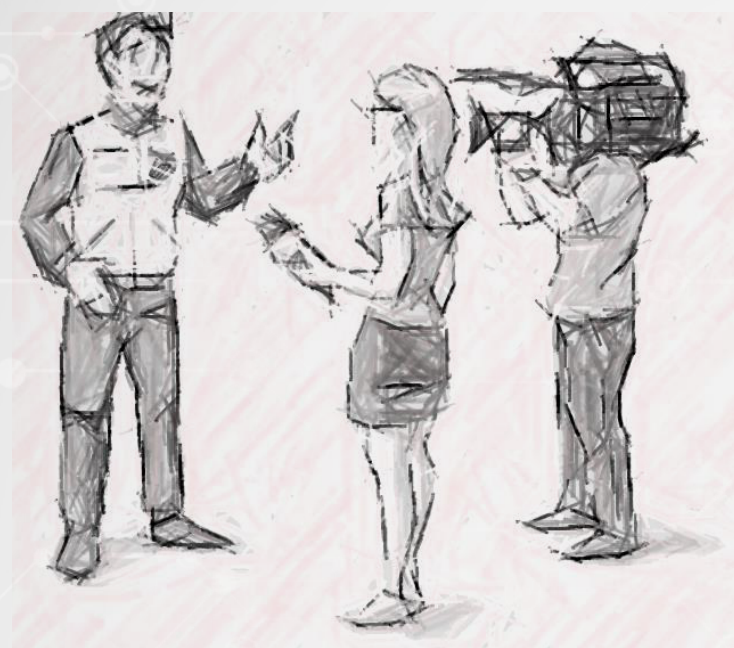

\subsection{La obsesión por el espectáculo}

Para los estudiosos de la comunicación el periodismo deportivo puede ser de mejor calidad, es decir, más profundo y riguroso, holístico, respetuoso de la ética, sin que estos aspectos riñan con los deseos de la audiencia de buscar entretenimiento en estos espectáculos, evasión de la rutina diaria $u$ otras razones. Algunas personas consideran al periodista y al periodismo deportivo como superficiales, justamente Rowe (2007, págs. 385-387) sostiene que una forma de subestimar la sección deportiva de los periódicos en los Estados Unidos era denominándola "sección de juguete", porque se pensaba con cierto prejuicio, que era la que se dedicaba a temas frívolos y superficiales.

Esa percepción puede estar motivada porque el periodista deportivo le da más prelación a los aspectos espectaculares de las competencias atléticas que a la rigurosidad informativa que, desde luego, debe ser aplicada a cualquier sección de contenidos. De acuerdo con Domínguez (2006), las formas de convertir en espectáculo cualquier disciplina deportiva y las performances de sus practicantes, se manifiestan en

la remembranza emotiva de antecedentes históricos, la exageración de la oposición o de las diferencias entre sí, la recuperación de aspectos inusitados aparentemente irrepetibles ("la primera vez", "lo mejor que ha ocurrido", "lo que nunca se ha visto", "lo más grande"), la atribución de rasgos personales o individuales ("inteligencia contra fuerza", "pasión contra razón", "discípulo contra maestro", "hermano contra hermano"), el empleo de términos belicistas (la batalla, los guerreros, las armas), el testimonio de los involucrados (jugadores, entrenadores, directivos, seguidores), la selección reiterativa de los momentos y escenas más impactantes, la invitación de comentaristas reconocidos (especialistas, jugadores legendarios, celebridades), la recreación humorística, la comercialización de productos alusivos (camiseta de los equipos, balones de fútbol, entradas especiales) y el llamado a la participación del público (encuestas, rifas, concursos).

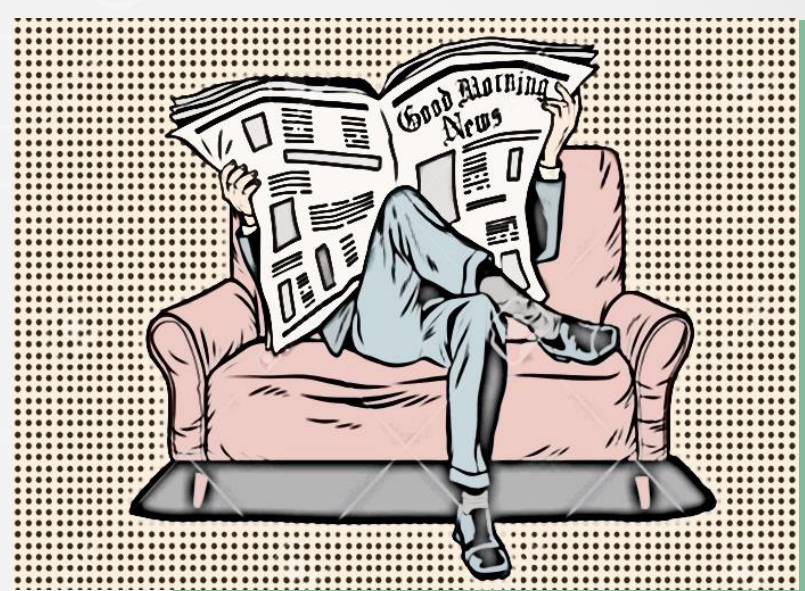

Para Mangone (1999, págs. 11-18), la espectacularización se refleja mediante:

El lenguaje bélico, para sublimar la guerra. El discurso del dramatismo, que supone la exageración de la trascendencia del deporte y de todas las peripecias que lo rodean, El sentido común, que es la forma como los amantes del deporte construyen sus propios correlatos en las interacciones diarias para explicar y reflexionar en torno al acontecimiento atlético, sin que medie una intención cientificista o pseudofilosófica. La minucia deportiva, que consiste en publicar detalles -muchas veces anodinos de las competencias. Las filosofías de vida, en tanto implican la construcción de la identidad personal y colectiva mediante la interacción social y las referencias semióticoculturales que promueven los equipos, las celebridades deportivas y los medios de comunicación. Una visión mítico-cíclica, estrategia que el márquetin y los medios de comunicación utilizan para acentuar los rasgos (garra), actitudes (inteligencia) y ejecuciones (picardía) de los protagonistas. El "nacionalismo" de la industria cultural, que 
pretende el reforzamiento de las identidades colectivas, apelando a la diferenciación cultural, política, religiosa. El racismo, que es consecuencia del uso del lenguaje bélico para aumentar las diferencias $y$, de esta forma, motivar obsesivamente las ansias de triunfo (o venganza) de los fans de un equipo sobre sus adversarios. La dimensión financiera: discurso y mercancía, pues el entorno deportivo está impregnado por el poder del dinero y la especulación financiera.

Según Labio (2009, pág. 163 y 164), el periodismo sobredimensiona el deporte al destacar sus aspectos espectaculares y aprovecha la fidelidad y admiración que un hincha tiene por un atleta o equipo con fines mercantilistas, lo cual da como resultado que los contenidos deportivos tiendan a evocar más que a informar.

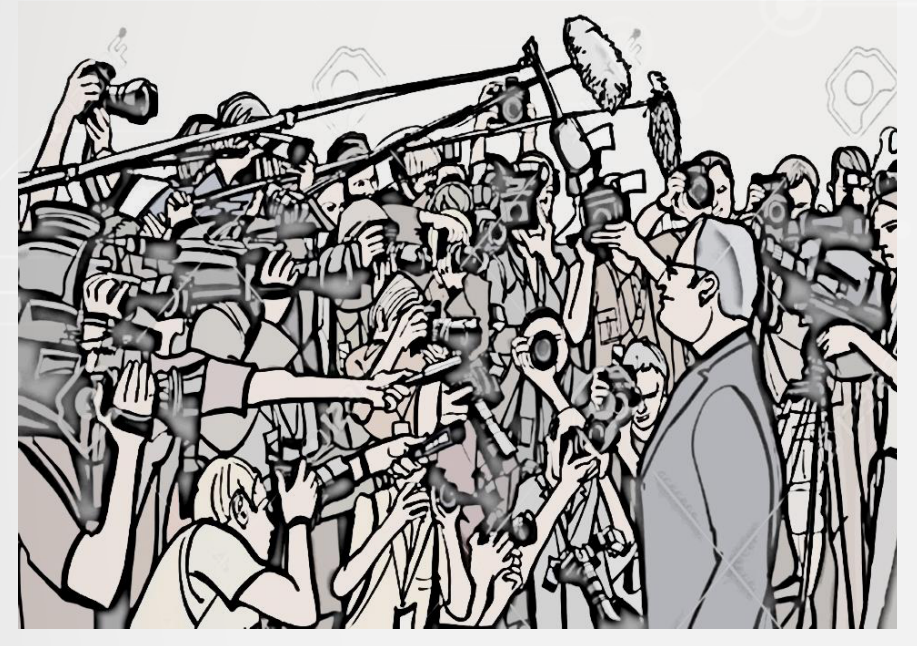

1.2 Las claves del lenguaje del periodismo deportivo

Para Alcoba (2005, pp. 118-154), el periodismo deportivo se expresa mediante seis lenguajes: el bélico, el escueto, el estético, semiológico, audiovisual y artístico. En el lenguaje bélico el autor destaca que sirve para darle color al culmen de la actividad agonística $\mathrm{y}$, por tanto, relativiza el hecho de que emplearlo de esa manera no contribuya a la paz y la deportividad. En ese mismo sentido se expresa Marrero (2011, pág. 76) cuando afirma que el objetivo de ese lenguaje es "lograr la descripción lo más fiel posible de lo intenso que fue o será el evento en cuestión". El lenguaje escueto se emplea cuando hay cierres de la edición de algún medio de comunicación. Aquí la redacción no tiene tantos adornos, ni géneros periodísticos más elaborados, puesto que no se dispone del suficiente tiempo y espacio. El lenguaje semiológico destaca el valor de los signos y los símbolos para connotar el impacto de la actividad atlética y competitiva en los espectadores, apelando al poder comunicativo y persuasivo de escudos y banderas de los equipos, etc.

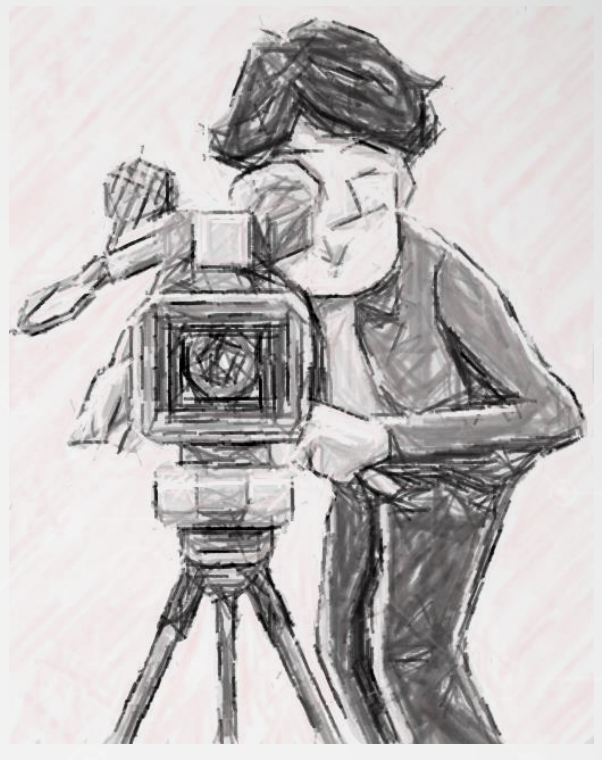

El lenguaje audiovisual potencia la concepción de "espectáculo deportivo", al propiciar la confluencia entre las narraciones, inflexiones de la voz y los distintos ángulos de las imágenes en movimiento. El lenguaje artístico es cada día más utilizado en el ámbito deportivo, desde el diseño arquitectónico vanguardista de estadios, coliseos y camisetas hasta la incursión de literatos e intelectuales en el comentario deportivo.

Bianchi (1991), por su parte, señala que la utilización de ese lenguaje, inclinado al fomento del espectáculo, lo margina a la subvaloración de su ejercicio por otros campos y disciplinas humanas y sociales. Por tanto, el periodista deportivo tiene que luchar constantemente por (1) moderar su fanatismo irracional y (2) cambiar la pobre valoración cultural que se tiene de su trabajo.

En el primer aspecto, es notorio cómo algunos de estos profesionales cargan sus transmisiones y escritos con expresiones apasionadas, más propias de un fanático que la de un comunicador que trata de ser independiente, veraz, plural y responsable. Por eso, sus columnas y crónicas -los géneros más usados en el periodismo deportivo- no pocas veces están cargados de sensacionalismo y amarillismo. En el segundo aspecto, no se puede desconocer que algunos periodistas deportivos carecen de un bagaje intelectual amplio, que les permita informar no solo sobre los aspectos competitivos de una disciplina y/o de un evento deportivo, sino también de las vinculaciones que estos tienen con otras ciencias (medicina, sociología, economía, derecho, entre otras). 
Fortalezas y debilidades del periodismo deportivo

Rojas (2011, págs. 36-98) realiza un análisis del periodismo deportivo desde sus fortalezas y debilidades, no sin antes señalar que esta especialidad es la más consumida y demandada por los ciudadanos y la que más ha evolucionado en la presentación original de propuestas narrativas y de imagen. Respecto a las fortalezas, el autor señala la universalidad y el desarrollo de un lenguaje propio. La universalidad se manifiesta con la capacidad para trascender a otros ámbitos, como los de la política y la economía, ya que muchos términos son prestados a estas áreas del conocimiento. Ello se debe a que las frases utilizadas en el periodismo deportivo pueden explicar de una manera sencilla temas complejos. Esta virtud tiene relación con el desarrollo de un lenguaje propio, puesto que

\footnotetext{
Entre las características definitorias del lenguaje deportivo podemos enumerar su alto grado de especialización, su afán innovador a la hora de crear nuevas palabras, expresiones y significados, así como su acusado retoricismo, lo que le lleva a recurrir de forma asidua a metáforas y otros usos figurados del lenguaje, cruces léxicos o juegos de palabras para elaborarmensajes sorprendentes e impactantes (38).
}

En el desarrollo de un lenguaje propio, no puede pasar inadvertido el lenguaje técnico. Puede parecer contradictorio el hecho de que su lenguaje llegue con facilidad a distintos públicos y que, al mismo tiempo, éste tenga un origen técnico en la medida en que las disciplinas deportivas tienen sus expresiones particulares. En realidad, este es el resultado de su propia evolución, ya que ha sabido combinar la naturalidad de sus términos con los tecnicismos de sus informaciones.

Los neologismos también hacen parte de su desarrollo. En este caso la creación de palabras pretende despertar el interés del público, a partir del uso de distintos recursos disponibles para cargar de originalidad sus contenidos. Estas licencias idiomáticas que desvían al periodismo deportivo del estándar común, si bien criticadas por los puristas de la lengua, son necesarias para mantener la eficacia y gusto de la audiencia por sus contenidos. Los préstamos léxicos son usuales en esta especialidad, puesto que, a pesar de las características singulares de los deportes, estos son terrenos contiguos en una sala de redacción. Estos traslados terminológicos sirven para enriquecer las crónicas y provocar creativas asociaciones en la audiencia. Finalmente, los juegos de palabras se constituyen en una estrategia para captar la atención del receptor, mediante el cambio de la grafía de las palabras por otras con un sonido similar. Este proceso se realiza con unas dosis de ingenio y humor.

Entre tanto, Rojas clasifica las debilidades en lo que denomina campo de conflicto idiomático, la primacía del espectáculo sobre la información, la incitación a la violencia, el sexismo informativo y la confusión entre información y opinión. En el campo del conflicto idiomático se incluyen los errores gramaticales comunes, las impropiedades léxicas (uso de palabras o expresiones existentes en nuestro idioma con significados equivocados), tópicos (utilización y abuso de expresiones gastadas que depauperan el mensaje), el abuso de extranjerismos, la reiteración de formas coloquiales y vulgarismo que no añaden información, así como la siglación excesiva y estilo fragmentario para acomodar textos a espacios y tiempos reducidos.

En la primacía del espectáculo sobre la información destaca (1) el sensacionalismo como un antivalor periodístico consistente en la magnificación gráfica y conceptual de los contenidos, con el fin de crear sensaciones, pero no el de informar; (2) la futbolización de la información deportiva, cuyos rasgos distintivos son la preeminencia del fútbol como el contenido que más espacio y tiempo ocupa en los medios de comunicación y la incorporación de las expresiones futbolística en otras disciplinas que cuentan con términos específicos para describir las reglas y desempeño de los atletas. Vale anotar que no informar sobre otros deportes implica:

(1) privar a la sociedad de una cultura y de unos valores deportivos más amplios que los que provee una sola actividad física y atlética; (2) no reconocer los esfuerzos que realizan otros atletas por figurar y representar a un país y (3) caer en la tentación de frivolizar el balompié, con seudonoticias que nada tienen que ver con sus aspectos trascendentes (Angulo, 2015, pág. 197 y 198).

La trivialización y criterios de selección no noticiosos, se presentan cuando se publican contenidos deportivos tomando como base los atractivos que puedan tener desde el punto de vista mercantil o sensacionalista. La consecuencia de ello son piezas periodísticas superficiales, sin calidad informativa, que para llamar la atención acuden al sobredimensionamiento de los acontecimientos o la inclusión de aspectos -como lo faranduleroque nada tienen que ver con la actividad atlética y competitiva.

La incitación a la violencia tiene tres componentes: 
el lenguaje bélico-militar si bien es un elemento distintivo del periodismo deportivo porque les da color a las informaciones llenándolas de metáforas a la guerra y la confrontación, no está por demás decir que el abuso y reiteración de expresiones bélicas y militares pueden impulsar a las personas a exacerbar la confrontación, las diferencias regionales y aumentar el odio irracional.

La exhibición de imágenes violentas es una forma de estimular el estupor en la audiencia, muchas veces sin ningún criterio estrictamente noticioso. Este punto se evidencia con la repetición obsesiva de imágenes sobre riñas en las graderías por barras bravas y los accidentes graves de deportistas, así como de las declaraciones ofensivas de contendientes para incrementar la rivalidad. La búsqueda del morbo y la confrontación es una práctica usual en los medios de comunicación y consiste en hallar la frase polémica, el gesto agresor, el símbolo violento, el cruce de expresiones malsonantes entre protagonistas de la práctica agonística, con el objeto de crear un ambiente inquietante y provocador. Esto puede adquirir una máxima peligrosidad en la medida en que caldea los ánimos, especialmente de los hinchas radicales, previo a un encuentro deportivo.

El sexismo informativo se manifiesta con la invisibilidad de la mujer deportista que puede ser causada por la hegemonía del fútbol, disciplina que culturalmente ha sido jugada y vista por hombre. La invisibilidad también es evidente cuando las palabras y las frases empleadas en el periodismo deportivo prescinden de la mujer o le dan un trato discriminatorio (sexismo lingüístico); y la transmisión de estereotipos y roles tradicionales se presencia en los contenidos, muchos de los cuales resaltan más el atractivo físico, la forma de vestir, la vida familiar o sentimental de la atleta que el desempeño deportivo, lo cual no suele suceder en el caso de los hombres.

La confusión entre informar y opinar comporta una hibridación de géneros propiciada por las excesivas licencias que se les da al periodismo deportivo para contar emotivamente un evento o suceso. Esta situación crea confusión en el destinatario y una sensación de ambigüedad en el emisor, en el mejor de los casos y en el peor una intención soterrada de éste por tomar partido de un hecho informativo.

Levinsky (2002) menciona otros males del periodismo deportivo tomando como referencia el que se practica en Argentina. Para este autor los males de esta especialidad se resumen en la falta de investigación, lo cual es evidente cuando los testimonios no se confrontan o no se utilizan las fuentes adecuadas. Como consecuencia de ello, el periodismo deportivo es poco dado a destapar actos corruptos, de ahí que Levinsky sugiera que los grandes directivos de Comités Olímpicos Internacionales y de la Federación Internacional de Fútbol Asociado, así como de entidades que manejan el deporte en cada país en ámbitos nacionales, regionales y locales, sean intocables pese a sus corruptas actuaciones.

\subsection{Violencia y sensacionalismo}

Dos males que se derivan de un periodismo deportivo mal practicado son la violencia y el sensacionalismo. La violencia no solo se detona con el uso de términos bélicos, sino con comentarios altisonantes, apasionados, que despiertan la ira y los miedos del ser humano. Los medios de comunicación han visto las confrontaciones como un espectáculo que hay que transmitir hasta la saciedad, aunque muchas veces se cuestionan con paños de agua tibia. Los enfrentamientos, producto del mal uso de los micrófonos y de las cámaras, se expresan en una triada: deportista-deportista, espectador-deportista y espectador-espectador, sin embargo, también es frecuente la actitud hostil del espectador y el deportista contra el reportero (Garrido, 2009, pág. 48).

Este tipo de contenidos ya son usuales en algunos medios (especialmente en televisión), pues, como es feroz la lucha que mantienen por las audiencias, muestran el lado más oscuro y sensacional para despertar estupor y morbo, en lugar de promover valores evaluando críticamente estas situaciones. La prensa escrita, en concreto la deportiva que a veces reemplaza las cabeceras sensacionalistas, igualmente acude a recursos expresivos con cierta exageración para captar más lectores. Los grandes titulares, con grandes tamaños de letras, fotografías que ocupan casi la página, con textos breves y superlativos, invitan al lector más a mirar que a leer.

Si así ocurre con la prensa y los medios visuales, la radio tampoco se libra estos males. En el periodismo deportivo, a diferencia de otras especialidades periodísticas, se le ha dado licencia para vociferar, gritar y demostrar sin ningún reparo su pasión por un deportista o equipo, situación inadmisible para el periodismo serio que aboga por la mesura, la responsabilidad social y la independencia. Podríamos decir que este profesional se sale de los márgenes éticos de la crónica y la columna, géneros en los que se admiten valoraciones, opiniones y juicios, para entrar en el terreno de la especulación, los insultos y las humillaciones. Garrido (2009) advierte que una de las características de la comunicación deportiva es su tendencia a evaluarlo todo (desempeño, organización, escenarios) y a 
todos (deportistas, árbitros, entrenadores, equipos), de modo que "todo es sometido al supremo juicio del periodista deportivo que, en ocasiones, actúa como un juez implacable".

Otra tendencia, agrega el autor, es la que se denomina retoricismo hueco, que, a nuestro juicio, está vinculado con la falta de innovación y creatividad de algunos reporteros y medios de comunicación para buscar historias atractivas, testimonios significativos y perfiles profundamente humanos de los protagonistas, sin caer en el amarillismo y la farándula. Quizás el conformismo y el afán por decir o por mostrar el acontecimiento de inmediato, lleva a que el periodista destaque lo banal y fútil, así como las frases de cajón de quienes intervienen directamente en la práctica agonística.

\section{Metodología}

Esta investigación se inscribe dentro del paradigma positivista que postula la posibilidad de "estudiar la sociedad y los objetos sociales de la misma manera como se estudian los fenómenos naturales" (Igartua, 2006, pág. 58). En este caso, se argumenta que se pueden analizar la comunicación mediada a través de las técnicas y métodos de las ciencias naturales.

De este se deriva el enfoque cuantitativo cuya naturaleza estriba en la recolección de datos numéricos, una relación deductiva entre teoría e investigación, predilección por los fundamentos de las ciencias naturales y una concepción objetivista de la realidad social (Bryman, 2005, pág. 50). El método que se usa para la extracción de los datos es el análisis de contenidos cuantitativo a las piezas periodísticas del periódico colombiano El Espectador.

Para Weerakkody este método se usa con el objeto de examinar a través de estudios longitudinales o de series temporales, cómo el cubrimiento que los medios de comunicación hacen de grupos o temas han cambiado con el tiempo o siguen siendo los mismos; formular preguntas de investigación y probar hipótesis en concordancia con la revisión teórica del objeto de estudio; servir como punto de partida para investigar los efectos de los medios, lo cual se logra, fundamentalmente, con la aplicación combinada de métodos cualitativos.

En este último aspecto, vale anotar que el análisis de contenidos también genera información cualitativa a través del cruce de variables, acción que se produce gracias a la habilidad del investigador para asociar y conectar los datos. De ahí a que, como lo sugiere Stokes (2003, pág. 56), no es un método netamente objetivo y empírico, pues con él hay mucho trabajo interpretativo por hacer, siempre que haya un buen conocimiento de los textos bajo examen.

El análisis de contenidos es un método que describe la agenda informativa de los medios, concretamente -como lo señala Vilches (2011) "la teoría de la agenda setting intenta superar la cuantificación descontextualizada de las noticias en un diario con el fin de integrarlo en diferentes contextos (económico, social, político, moral, geográfico, etc.) y, al mismo tiempo, resaltar la importancia de los procesos de tematización periodística". Entre tanto, Wimmer y Dominick señalan que una de las funciones principales de este método consiste en comprobar el contenido de los medios con el mundo real.

En esta investigación se toman en consideración estas dos perspectivas: la descripción de la agenda informativa del periódico en cuanto el tipo de deporte, fuentes, enfoque temático, calidad de las piezas periodísticas, etc., y la comparación de estos resultados con la realidad deportiva nacional e internacional, esto es, si existe coherencia entre lo que se informa con lo que ocurre en el variado acontecimiento deportivo en Colombia y el mundo.

En esta investigación nos preguntamos: ¿Cuál es el tipo de deporte, género periodístico, tipo de titular y fuentes que predominan en los contenidos deportivos de El Espectador? ¿Cuál es el tamaño de la pieza periodística por deporte informado? ¿Cuáles son los enfoques temáticos más informados y opinados? ¿Qué importancia les da el medio a sus contenidos deportivos? ¿Cómo estos aspectos contribuyen a la calidad periodística?

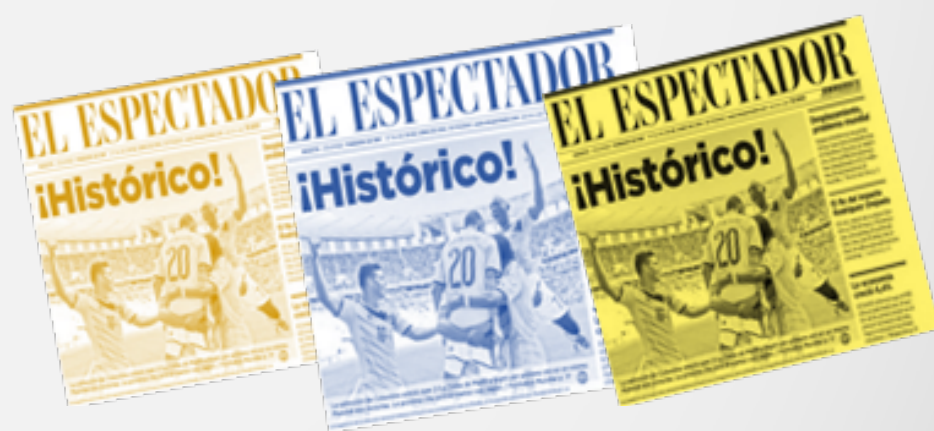

Se contemplaron tres tipos de muestras: de medios, temporal y de contenidos. Muestra de medios: de los cuatro periódicos diarios, generalistas de Colombia, se seleccionó a El Espectador, toda vez que es un medio de los que encajan en la categoría de serios, con 128 años de funcionamiento; tiene una cobertura nacional; posee una sección fija de deportes y posee 238.965 lectores fieles en formato papel y los líderes de opinión consultan su web en un 15\% (La República, 2012) y (Semana, 2014). Muestra temporal: la muestra utilizada es la aleatoria, sistemática con semanas compuestas, 
aplicada a los años 2011 y 2012. De acuerdo con Riffe et al. (1993 y 1996, citados en Wimmer \& Dominick, 1996), quienes llevaron a cabo una serie de comparaciones entre distintos tipos y tamaños de muestras para periódicos diarios y noticieros de televisión, con el ánimo de determinar qué tipo y tamaño era el más conveniente y fiable, concluyeron que una muestra de dos semanas compuestas es suficiente para conocer con significativa validez el contenido de un periódico diario durante un año. Con esto en mente, nos parece razonable emplear una muestra de tres semanas compuestas (una más que la recomendada por Riffe y sus colegas) para cado año, esto es, 21 ejemplares del año 2011 y otros 21 ejemplares del 2012.

Muestra de contenidos: el análisis se concentró en los contenidos deportivos, ubicados en distintas secciones del periódico. No solo en la sección deportiva.

Los textos del periódico El Espectador se analizan en dos planos de análisis: en los textos informativo/ interpretativos y en los textos de opinión, debido a que en los primeros es evidente encontrar algunos ítems (fuentes, tratamiento fotográfico, tamaño, tipo de titular y Escala de Budd (1964), que no se presentan o no son de nuestro interés en los textos de opinión. Adicionalmente, para determinar la importancia que el periódico El Espectador le da a la información deportiva, se emplea la Escala de Budd (1964), adaptada por Moreno.

Tabla 1.

Escala de Budd y su baremo de puntuación

\begin{tabular}{|l|l|c|}
\hline \multirow{2}{*}{ 1. Tamaño } & Titular a 2 columnas & 2 \\
\cline { 2 - 3 } & Titular a 3 o más columnas & 3 \\
\hline 2. Espacio & $\begin{array}{l}\text { Más de 3/4 de página incluidas } \\
\text { fotografías }\end{array}$ & 1 \\
\hline 3. Lugar de la página & Si aparece en la 1/2 superior & 1 \\
\hline \multirow{2}{*}{ 4. Primera página } & Noticia principal en portada & 2 \\
\cline { 2 - 3 } $\begin{array}{l}\text { 5. Otro tipo de por- } \\
\text { tada }\end{array}$ & $\begin{array}{l}\text { Aparición en portada de sección } \\
\text { o contraportada }\end{array}$ & 1 \\
\hline \multirow{2}{*}{ 6. Ilustraciones } & Infográficos & 1,5 \\
\cline { 2 - 3 } & Fotografías & 0,5 \\
\hline \multicolumn{2}{|l|}{ Puntuación Máxima } & 10 \\
\hline
\end{tabular}

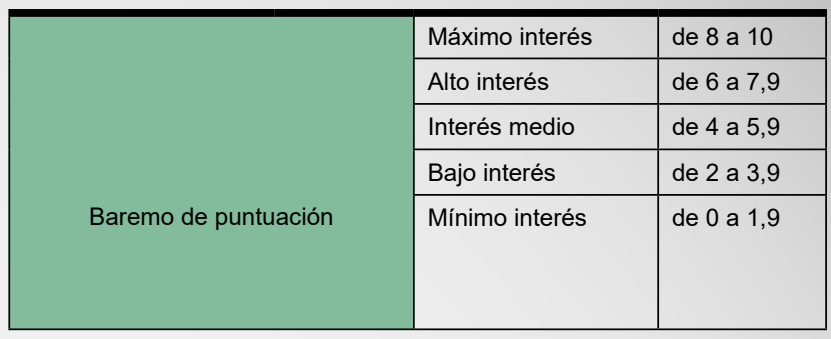

Fuente. Budd (1964) y Moreno (2011)

Consideraciones éticas. Esta investigación se ajusta a los parámetros éticos contemplados por Wimmer y Dominick (1996, pág. 428), según los cuales: se describe al detalle los planteamientos metodológicos para la verificación de los datos extraídos de las muestras y las conclusiones del estudio se derivan del estricto análisis de los datos y no a intereses particulares de los autores.

\section{Resultados}

Una vez realizada la codificación del periódico El Espectador de los años 2011 y 2012, se presentan aquí el análisis e interpretación de los resultados en dos dimensiones: la de los textos pertenecientes a los géneros informativo e interpretativo y al género de opinión.

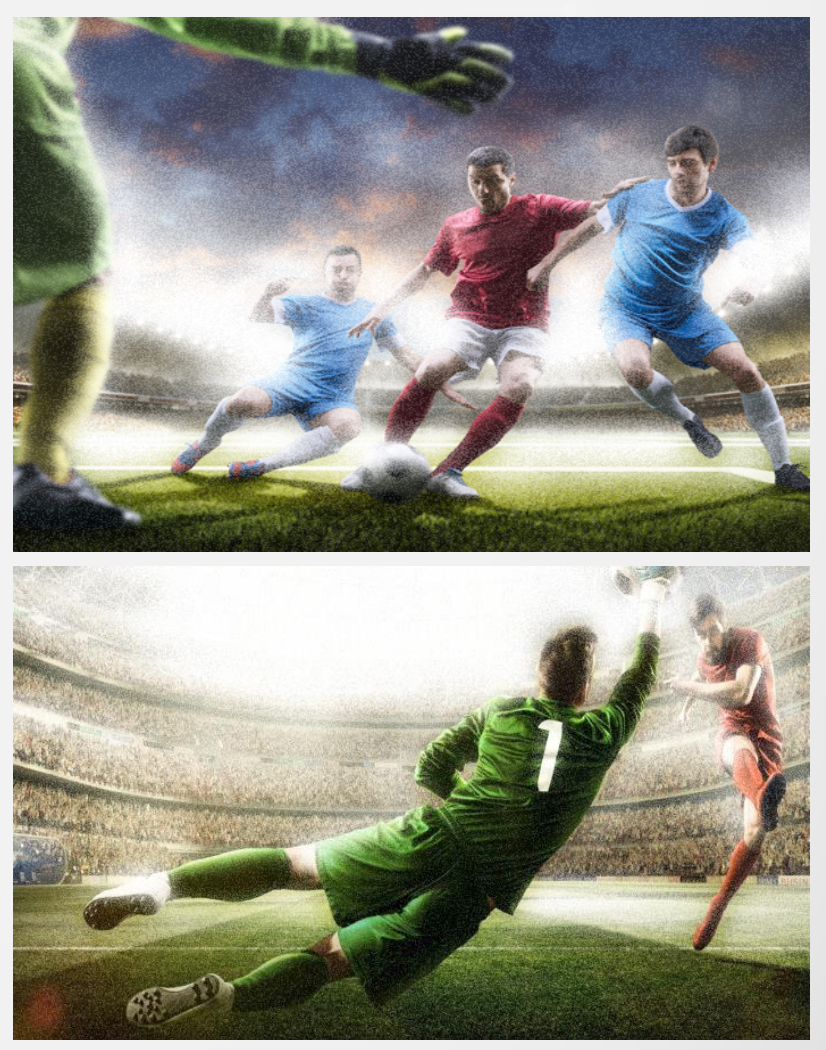


Géneros informativo e interpretativo

\subsubsection{Tipo de deporte}

El periódico El Espectador concede la mayoría del espacio $(90,6 \%)$ a deportes Olímpicos/federados de Colombia. Solo destina un $2,9 \%$ del diario a las disciplinas no olímpicas, como las que se presentaron en los Juegos Mundiales de Cali (Colombia) en el 2013, las cuales son reconocidas por el Comité Olímpico Internacional pero que no forman parte de los Juegos Olímpicos. Los comunitarios/autóctonos (1\%), como el bolo criollo, el senderismo/caminatas y los autóctonos indígenas, los extremos $(0,8 \%)$ y paraolímpicos (1\%), no tienen porcentajes significativos. El conjunto de deportes representa un $3,4 \%$ de la codificación.

Evidentemente, este periódico generalista le da más despliegue a aquellos deportes que tienen el respaldo de una federación nacional e internacional y que, por tradición, son los que han concentrado la atención de los medios de comunicación internacionales, incluidas las agencias de prensa. Vale anotar que resulta muy difícil, en todo caso, que se informe sobre los 119 deportes que incluimos en la matriz de codificación.

\section{Gráfico N1. Tipo de deporte}

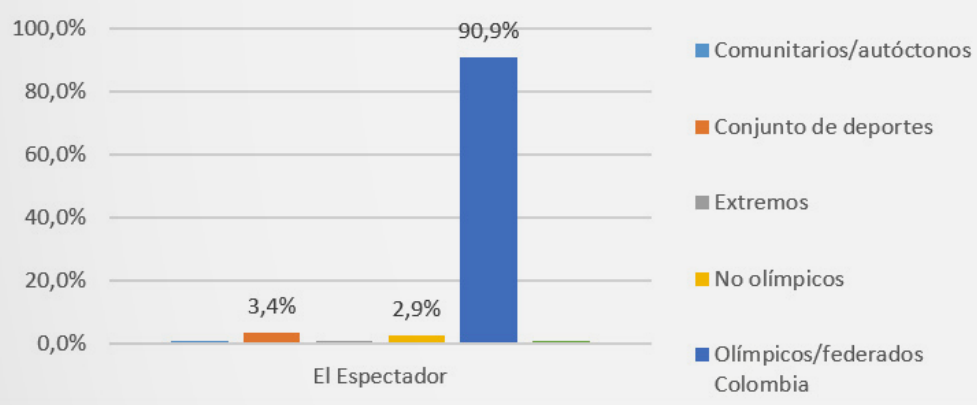

Fuente: elaboración propia. $\mathrm{N}=385$ piezas periodísticas

\subsubsection{Deporte}

En la categoría deporte, de los 119 incluidos por el autor en la matriz de codificación, aparecen 40 a los que se les dedica un espacio informativo en El Espectador. Ahora bien, en la categoría de Olímpicos/federados Colombia $(90,9 \%)$, los deportes que más se publican son fútbol $(43,1 \%)$; tenis $(14,3 \%)$, y ciclismo $(11,2 \%)$.

En la categoría de paraolímpicos, se rescata la presencia del tenis paraolímpico $(0,5 \%)$; en la categoría no olímpicos, el fútbol de salón $(0,8 \%)$ y en el resto de categorías, esto es, comunitarios/ autóctonos y extremos se concluye que se informa sobre pocos de esos deportes (tres en promedio) y en escasa frecuencia (entre 0,3 y $0,5 \%$ ).

Tabla 2.

Deporte

\begin{tabular}{|c|c|c|}
\hline Tipo de deporte y deporte & El Espectador & $\begin{array}{lllll}\mathrm{T} & \mathrm{o} & \mathrm{t} & \mathrm{a} & \mathrm{I} \\
\text { general } & & \end{array}$ \\
\hline Comunitarios/autóctonos & $1,0 \%$ & $1,0 \%$ \\
\hline Ciclovías & $0,5 \%$ & $0,5 \%$ \\
\hline Senderismo/caminatas & $0,5 \%$ & $0,5 \%$ \\
\hline Conjunto de deportes & $3,4 \%$ & $3,4 \%$ \\
\hline Varios & $3,4 \%$ & $3,4 \%$ \\
\hline Extremos & $0,8 \%$ & $0,8 \%$ \\
\hline BMX & $0,3 \%$ & $0,3 \%$ \\
\hline Roller & $0,3 \%$ & $0,3 \%$ \\
\hline Skate & $0,3 \%$ & $0,3 \%$ \\
\hline No olímpicos & $2,9 \%$ & $2,9 \%$ \\
\hline Artes marciales no olímpicas & $0,5 \%$ & $0,5 \%$ \\
\hline Bolo & $0,3 \%$ & $0,3 \%$ \\
\hline Disco volador & $0,3 \%$ & $0,3 \%$ \\
\hline Escalada deportiva & $0,3 \%$ & $0,3 \%$ \\
\hline Fútbol de salón & $0,8 \%$ & $0,8 \%$ \\
\hline Hockey en línea & $0,3 \%$ & $0,3 \%$ \\
\hline Patinaje de velocidad y ruta & $0,5 \%$ & $0,5 \%$ \\
\hline Olímpicos/federados Colombia & $90,9 \%$ & $90,9 \%$ \\
\hline Acuáticos & $1,3 \%$ & $1,3 \%$ \\
\hline Atletismo & $6,5 \%$ & $6,5 \%$ \\
\hline Automovilismo & $3,1 \%$ & $3,1 \%$ \\
\hline Baloncesto & $1,6 \%$ & $1,6 \%$ \\
\hline Béisbol & $1,6 \%$ & $1,6 \%$ \\
\hline Boxeo & $0,5 \%$ & $0,5 \%$ \\
\hline Ciclismo & $11,2 \%$ & $11,2 \%$ \\
\hline 1.1.1 Ecuestre & $0,3 \%$ & $0,3 \%$ \\
\hline Equitación & $0,3 \%$ & $0,3 \%$ \\
\hline Fútbol & $43,1 \%$ & $43,1 \%$ \\
\hline Gimnasia & $0,5 \%$ & $0,5 \%$ \\
\hline Golf & $2,3 \%$ & $2,3 \%$ \\
\hline Halterofilia & $0,8 \%$ & $0,8 \%$ \\
\hline Hockey Césped & $0,3 \%$ & $0,3 \%$ \\
\hline Judo & $0,8 \%$ & $0,8 \%$ \\
\hline Lucha & $0,3 \%$ & $0,3 \%$ \\
\hline Motociclismo & $0,3 \%$ & $0,3 \%$ \\
\hline Otro & $0,3 \%$ & $0,3 \%$ \\
\hline Subacuáticos & $0,3 \%$ & $0,3 \%$ \\
\hline Taekwondo & $0,3 \%$ & $0,3 \%$ \\
\hline Tenis & $14,3 \%$ & $14,3 \%$ \\
\hline Tiro con arco & $0,3 \%$ & $0,3 \%$ \\
\hline Tiro olímpico & $0,3 \%$ & $0,3 \%$ \\
\hline Varios & $0,3 \%$ & $0,3 \%$ \\
\hline
\end{tabular}




\begin{tabular}{|l|l|l|} 
Voleibol & $0,5 \%$ & $0,5 \%$ \\
\hline Paraolímpicos & $1,0 \%$ & $1,0 \%$ \\
\cline { 1 - 1 } Baloncesto paraolímpico & $0,3 \%$ & $0,3 \%$ \\
Tenis paraolímpico & $0,5 \%$ & $0,5 \%$ \\
Varios & $0,3 \%$ & $0,3 \%$ \\
\hline Total general & $100,0 \%$ & $100,0 \%$ \\
\hline
\end{tabular}

Fuente: elaboración propia. $\mathrm{N}=385$ piezas periodísticas

\subsubsection{Género periodístico}

Es notoria la frecuencia con que se utiliza el género informativo en El Espectador: $41,6 \%$ en breves y $25,7 \%$ en noticias, para un total de $67,3 \%$, lo que sugiere una atadura a los cánones de la columna invertida para informar a los lectores. Cabe destacar que aquí también podríamos incluir las anécdotas/estadísticas (1,8\%), la fotonoticia $(3,4 \%)$, resultados/clasificaciones $(0,3 \%)$ y la infografía $(0,3 \%)$, géneros que deberían tener un espacio más amplio -especialmente las anécdotas/estadísticas y la infografíapara que el reporte a los lectores sea más atractivo y de calidad.

No obstante, se resalta un porcentaje relativamente significativo de crónicas $(9,9 \%)$ y entrevistas (10,1\%), pertenecientes al género interpretativo, las cuales añaden color, conclusiones interesantes y reflexiones llamativas.

\section{Gráfico N2. Género informativo/ interpretativo}

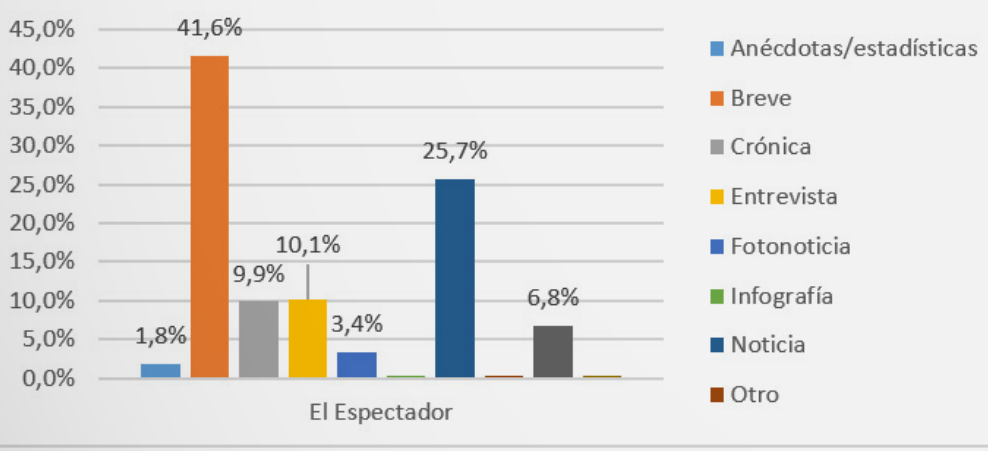

Fuente: elaboración propia. $\mathrm{N}=385$ piezas periodísticas

\subsubsection{Tamaño por deporte informado}

En la tabla N3, se indica el tamaño empleado por el periódico para reportar deportes, pero no establece cuál es el espacio ocupado por disciplina. Pues bien, en esta tabla se presenta esta última información, y se concluye que -como era de esperarse- el fútbol tienen los porcentajes más altos para las dimensiones mayores, así: grande 50\%, mediano $60 \%$, muy grande $51,9 \%$ y pequeño $38 \%$. Lo mismo ocurre con el tenis: grande $30 \%$, mediano $4,4 \%$, muy grande $22,2 \%$ y pequeño $12,2 \%$. El ciclismo, pese a ser el deporte nacional, aparece con un $11,1 \%$ en tamaño muy grande, $14,1 \%$ en pequeño y solo un $2 \%$ en grande.

Es evidente, entre tanto, que los deportes minoritarios únicamente se publican en el tamaño pequeño: tiro olímpico $(0,4 \%)$, equitación $(0,4 \%)$, por citar dos ejemplos. El patinaje de velocidad y ruta, tiene apenas un $0,8 \%$ de espacio en la categoría de pequeño.

Tabla 3. Tamaño por deporte informado

\begin{tabular}{|l|l|l|l|l|l|}
\hline Etiquetas de fila & Grande & Mediano & $\begin{array}{l}\text { M } \\
\text { grande }\end{array}$ & $\begin{array}{l}\text { Peque- } \\
\text { ño }\end{array}$ & $\begin{array}{l}\text { Total ge- } \\
\text { neral }\end{array}$ \\
\hline El Espectador & $100,0 \%$ & $100,0 \%$ & $100,0 \%$ & $100,0 \%$ & $100,0 \%$ \\
\hline Acuáticos & $2,0 \%$ & $0,0 \%$ & $0,0 \%$ & $1,5 \%$ & $1,3 \%$ \\
\hline $\begin{array}{l}\text { Artes marciales no } \\
\text { olímpicas }\end{array}$ & $0,0 \%$ & $0,0 \%$ & $0,0 \%$ & $0,8 \%$ & $0,5 \%$ \\
\hline Atletismo & $2,0 \%$ & $6,7 \%$ & $7,4 \%$ & $7,2 \%$ & $6,5 \%$ \\
\hline Automovilismo & $2,0 \%$ & $4,4 \%$ & $0,0 \%$ & $3,4 \%$ & $3,1 \%$ \\
\hline Baloncesto & $0,0 \%$ & $4,4 \%$ & $0,0 \%$ & $1,5 \%$ & $1,6 \%$ \\
\hline $\begin{array}{l}\text { Baloncesto parao- } \\
\text { límpico }\end{array}$ & $0,0 \%$ & $0,0 \%$ & $0,0 \%$ & $0,4 \%$ & $0,3 \%$ \\
\hline Béisbol & $2,0 \%$ & $2,2 \%$ & $0,0 \%$ & $1,5 \%$ & $1,6 \%$ \\
\hline BMX & $0,0 \%$ & $0,0 \%$ & $0,0 \%$ & $0,4 \%$ & $0,3 \%$ \\
\hline Bolo & $0,0 \%$ & $0,0 \%$ & $0,0 \%$ & $0,4 \%$ & $0,3 \%$ \\
\hline Boxeo & $0,0 \%$ & $0,0 \%$ & $0,0 \%$ & $0,8 \%$ & $0,5 \%$ \\
\hline Ciclismo & $2,0 \%$ & $4,4 \%$ & $11,1 \%$ & $14,1 \%$ & $11,2 \%$ \\
\hline Ciclovías & $0,0 \%$ & $0,0 \%$ & $0,0 \%$ & $0,8 \%$ & $0,5 \%$ \\
\hline Disco volador & $0,0 \%$ & $0,0 \%$ & $0,0 \%$ & $0,4 \%$ & $0,3 \%$ \\
\hline Ecuestre & $0,0 \%$ & $0,0 \%$ & $0,0 \%$ & $0,4 \%$ & $0,3 \%$ \\
\hline Equitación & $0,0 \%$ & $0,0 \%$ & $0,0 \%$ & $0,4 \%$ & $0,3 \%$ \\
\hline Escalada deportiva & $0,0 \%$ & $0,0 \%$ & $0,0 \%$ & $0,4 \%$ & $0,3 \%$ \\
\hline Fútbol & $50,0 \%$ & $60,0 \%$ & $51,9 \%$ & $38,0 \%$ & $43,1 \%$ \\
\hline Fútbol de salón & $0,0 \%$ & $2,2 \%$ & $0,0 \%$ & $0,8 \%$ & $0,8 \%$ \\
\hline Gimnasia & $0,0 \%$ & $0,0 \%$ & $0,0 \%$ & $0,8 \%$ & $0,5 \%$ \\
\hline Golf & $2,0 \%$ & $2,2 \%$ & $0,0 \%$ & $2,7 \%$ & $2,3 \%$ \\
\hline Halterofilia & $0,0 \%$ & $2,2 \%$ & $0,0 \%$ & $0,8 \%$ & $0,8 \%$ \\
\hline Hockey Césped & $0,0 \%$ & $0,0 \%$ & $0,0 \%$ & $0,4 \%$ & $0,3 \%$ \\
\hline Hockey en línea & $0,0 \%$ & $0,0 \%$ & $0,0 \%$ & $0,4 \%$ & $0,3 \%$ \\
\hline Judo & $0,0 \%$ & $0,0 \%$ & $0,0 \%$ & $1,1 \%$ & $0,8 \%$ \\
\hline Lucha & $0,0 \%$ & $0,0 \%$ & $0,0 \%$ & $0,4 \%$ & $0,3 \%$ \\
\hline Motociclismo & $0,0 \%$ & $0,0 \%$ & $3,7 \%$ & $0,0 \%$ & $0,3 \%$ \\
\hline Otro & $0,0 \%$ & $0,0 \%$ & $0,4 \%$ & $0,3 \%$ \\
\hline Patinaje de veloci- & $0,0 \%$ & $0,0 \%$ & $0,8 \%$ & $0,5 \%$ \\
\hline
\end{tabular}




\begin{tabular}{|l|l|l|l|l|l|}
\hline Roller & $0,0 \%$ & $0,0 \%$ & $0,0 \%$ & $0,4 \%$ & $0,3 \%$ \\
\hline $\begin{array}{l}\text { Senderismo/cami- } \\
\text { natas }\end{array}$ & $0,0 \%$ & $0,0 \%$ & $0,0 \%$ & $0,8 \%$ & $0,5 \%$ \\
\hline Skate & $0,0 \%$ & $0,0 \%$ & $0,0 \%$ & $0,4 \%$ & $0,3 \%$ \\
\hline Subacuáticos & $0,0 \%$ & $0,0 \%$ & $0,0 \%$ & $0,4 \%$ & $0,3 \%$ \\
\hline Taekwondo & $0,0 \%$ & $0,0 \%$ & $0,0 \%$ & $0,4 \%$ & $0,3 \%$ \\
\hline Tenis & $30,0 \%$ & $4,4 \%$ & $22,2 \%$ & $12,2 \%$ & $14,3 \%$ \\
\hline Tenis paraolímpico & $2,0 \%$ & $0,0 \%$ & $0,0 \%$ & $0,4 \%$ & $0,5 \%$ \\
\hline Tiro con arco & $0,0 \%$ & $0,0 \%$ & $0,0 \%$ & $0,4 \%$ & $0,3 \%$ \\
\hline Tiro olímpico & $0,0 \%$ & $0,0 \%$ & $0,0 \%$ & $0,4 \%$ & $0,3 \%$ \\
\hline Varios & $6,0 \%$ & $6,7 \%$ & $3,7 \%$ & $3,0 \%$ & $3,9 \%$ \\
\hline Voleibol & $0,0 \%$ & $0,0 \%$ & $0,0 \%$ & $0,8 \%$ & $0,5 \%$ \\
\hline Total general & $100,0 \%$ & $100,0 \%$ & $100,0 \%$ & $100,0 \%$ & $100,0 \%$ \\
\hline
\end{tabular}

la actividad y desempeño. Otros enfoques como los de la relación entre deporte y economía $(2,9 \%)$, farándula $(2,6 \%)$, justicia $(3,1 \%)$, política $(2,1 \%)$ y salud/medicina/psicología (2,3\%), presentan valores mínimos por lo que el conocimiento holístico del deporte pareciera ser limitado.

Tabla 4. Enfoque temático

Fuente: elaboración propia. $\mathrm{N}=385$ piezas periodísticas

\subsubsection{Tipo de titular}

Existe un predominio de titulares informativos $(38,2 \%)$, expresivos $(33,2 \%)$ y, en menor porcentaje, apelativos $(15,8 \%)$. Los informativos son los que suelen identificar al protagonista con su acción y consecuencia, mientras que los expresivos y apelativos son cortos y tienden a crear sensaciones más que a informar.

\section{Gráfico N3. Tipo de titular}

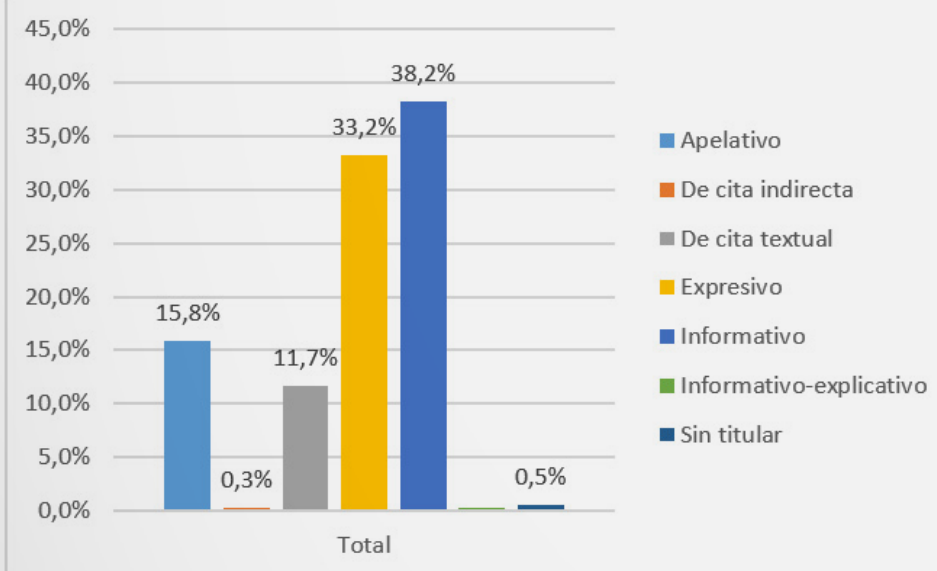

Fuente: elaboración propia. $\mathrm{N}=385$ piezas periodísticas

\subsubsection{Enfoque temático}

El incorporar el enfoque temático tiene como propósito determinar hasta qué punto existe el interés por una visión holística de la información deportiva. Desde este contexto, se demuestra que el enfoque más frecuente es el del ámbito competitivo/ anecdótico/resultados $(78,2 \%)$, esto es, el que se refiere a la práctica agonística en sí misma, que incorpora datos sobre preparación, realización de

\begin{tabular}{|l|l|}
\hline El Espectador & $100,0 \%$ \\
\hline Competitivo/anecdótico/resultados & $78,2 \%$ \\
\hline Deporte y comunicación & $0,5 \%$ \\
\hline Deporte y cultura & $1,8 \%$ \\
\hline Deporte y ecología & $0,8 \%$ \\
\hline Deporte y economía & $2,9 \%$ \\
\hline Deporte y educación & $1,0 \%$ \\
\hline Deporte y farándula & $2,6 \%$ \\
\hline Deporte y género & $0,5 \%$ \\
\hline Deporte y justicia & $3,1 \%$ \\
\hline Deporte y política & $2,1 \%$ \\
\hline Deporte y religión & $1,0 \%$ \\
\hline Deporte y sociología & $0,8 \%$ \\
\hline Deporte y tecnología & $0,3 \%$ \\
\hline Deporte/salud/medicina/psicología & $2,3 \%$ \\
\hline Historia del deporte & $1,6 \%$ \\
\hline Otro & $0,3 \%$ \\
\hline Varios & $0,3 \%$ \\
\hline Total general & $100,0 \%$ \\
\hline
\end{tabular}

Fuente: elaboración propia. $\mathrm{N}=385$ piezas periodísticas

\subsubsection{Fuentes}

Las fuentes que más se consultan en El Espectador son en su orden, deportistas $(46,9 \%)$, entrenadores $(20,1 \%)$, intermediario/representante $(8,9 \%)$, esto es, apoderados, familiares, amigos. Es curioso que el gobierno $(3,4 \%)$ se le cite muy poco, y mucho menos se hace con la oposición $(0,6)$ El Comité Olímpico Colombiano $(0,6 \%)$, Coldeportes $(1,1 \%)$ (Órgano rector de esta actividad en Colombia), club $(0,6 \%)$ y Federación $(1,7 \%)$, son fuentes consultadas con poca asiduidad. Hay que resaltar que aficionados y árbitros no se citan en los textos. Otro aspecto de relevancia estriba en que de los 385 textos codificados, 261 (68\%) no tienen fuentes (muchos de éstos son breves noticiosas) y solo 126 $(32 \%)$ sí las tienen. 
Tabla 5.

Fuentes

\begin{tabular}{|l|l|}
\hline El Espectador & $100,0 \%$ \\
\hline Club & $0,6 \%$ \\
\hline Coldeportes & $1,1 \%$ \\
\hline Comité Olímpico Colombiano & $0,6 \%$ \\
\hline Deportista & $46,9 \%$ \\
\hline Directivo & $6,7 \%$ \\
\hline Entrenador & $20,1 \%$ \\
\hline Evento deportivo & $1,1 \%$ \\
\hline Exdeportista & $2,2 \%$ \\
\hline Federación & $1,7 \%$ \\
\hline Gobierno & $3,4 \%$ \\
\hline Instituto de educación & $1,1 \%$ \\
\hline Intermediario/representante & $8,9 \%$ \\
\hline Medios de comunicación & $3,9 \%$ \\
\hline Oposición & $0,6 \%$ \\
\hline Otro & $1,1 \%$ \\
\hline Total general & $100,0 \%$ \\
\hline
\end{tabular}

Fuente: elaboración propia. $\mathrm{N}=385$ piezas periodísticas

\subsubsection{Interés por la información deportiva}

El Espectador le da un interés relativo a la información deportiva, pues de ella el $11,4 \%$ es de alto interés y solo un $2,1 \%$ es de máximo interés. Este tipo de textos usualmente son portada de sección o aparecen de distintas formas en primera página del diario, son extensas y combinan recursos como fotografía e infografía, entre otros indicadores. El $24,9 \%$ de estas notas son de interés medio, el $34,5 \%$ son de bajo interés y el $27 \%$ de mínimo interés.

Gráfico N 4. Interés por la información deportiva

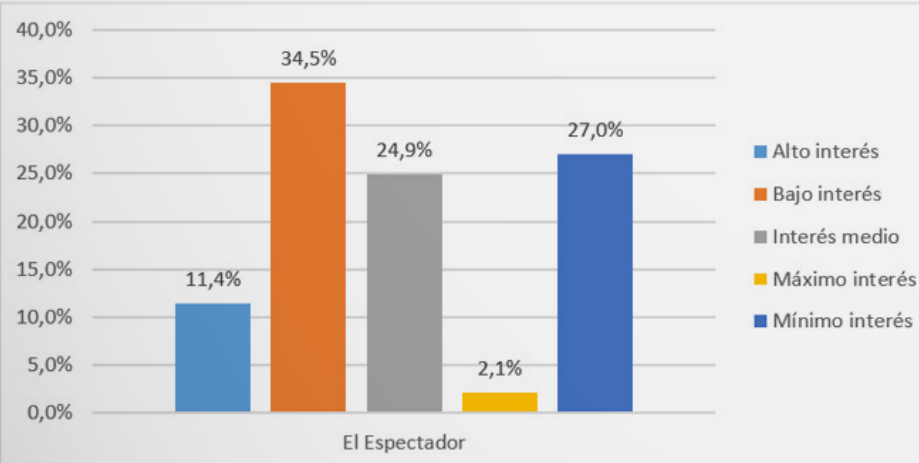

Fuente: elaboración propia. $\mathrm{N}=385$ piezas periodísticas
3.1.9 Interés del periódico por determina deportes

Como era de suponerse, el fútbol y el tenis son los que acaparan el mayor interés de El Espectador. Así lo indican los porcentajes: fútbol: máximo interés (75\%) y alto interés $(54,5 \%)$; tenis: máximo interés $(12,5 \%)$ y alto interés $(13,6 \%)$. El ciclismo, el deporte nacional y el que más títulos le ha dado al país solo recibe un alto interés en un $4,5 \%$. Sin embargo, el atletismo, disciplina que empieza sobresalir en el país, obtiene un significativo $12,5 \%$ de máximo interés y un $4,5 \%$ de alto interés. Otros deportes captan la atención del diario en forma coyuntural, esto es, cuando se obtiene un título mundial, panamericano, olímpico, etc., como en el alto interés que reciben los acuáticos, el automovilismo, el patinaje de velocidad y ruta, la gimnasia, el golf, la halterofilia y el béisbol, todos ellos con un 2,3\%.

Tabla 6

Interés del periódico por determinados deportes

\begin{tabular}{|c|l|l|l|l|l|l|}
\hline Etiquetas de fila & $\begin{array}{c}\text { Alto } \\
\text { interés }\end{array}$ & $\begin{array}{c}\text { Bajo } \\
\text { interés }\end{array}$ & $\begin{array}{c}\text { Interés } \\
\text { medio }\end{array}$ & $\begin{array}{c}\text { Máximo } \\
\text { interés }\end{array}$ & $\begin{array}{c}\text { Mínimo } \\
\text { interés }\end{array}$ & $\begin{array}{c}\text { Total } \\
\text { general }\end{array}$ \\
\hline $\begin{array}{c}\text { El } \\
\text { Espectador }\end{array}$ & $100,0 \%$ & $100,0 \%$ & $100,0 \%$ & $100,0 \%$ & $100,0 \%$ & $100,0 \%$ \\
\hline Acuáticos & $2,3 \%$ & $0,0 \%$ & $0,0 \%$ & $0,0 \%$ & $3,8 \%$ & $1,3 \%$ \\
\hline $\begin{array}{c}\text { Artes marciales no } \\
\text { olímpicas }\end{array}$ & $0,0 \%$ & $0,0 \%$ & $0,0 \%$ & $0,0 \%$ & $1,9 \%$ & $0,5 \%$ \\
\hline Atletismo & $4,5 \%$ & $8,3 \%$ & $1,0 \%$ & $12,5 \%$ & $9,6 \%$ & $6,5 \%$ \\
\hline Automovilismo & $2,3 \%$ & $4,5 \%$ & $2,1 \%$ & $0,0 \%$ & $2,9 \%$ & $3,1 \%$ \\
\hline Baloncesto & $0,0 \%$ & $1,5 \%$ & $2,1 \%$ & $0,0 \%$ & $1,9 \%$ & $1,6 \%$ \\
\hline $\begin{array}{c}\text { Baloncesto } \\
\text { paraolímpico }\end{array}$ & $0,0 \%$ & $0,0 \%$ & $0,0 \%$ & $0,0 \%$ & $1,0 \%$ & $0,3 \%$ \\
\hline Béisbol & $2,3 \%$ & $1,5 \%$ & $2,1 \%$ & $0,0 \%$ & $1,0 \%$ & $1,6 \%$ \\
\hline BMX & $0,0 \%$ & $0,0 \%$ & $0,0 \%$ & $0,0 \%$ & $1,0 \%$ & $0,3 \%$ \\
\hline Bolo & $0,0 \%$ & $0,0 \%$ & $0,0 \%$ & $0,0 \%$ & $1,0 \%$ & $0,3 \%$ \\
\hline Boxeo & $0,0 \%$ & $0,8 \%$ & $0,0 \%$ & $0,0 \%$ & $1,0 \%$ & $0,5 \%$ \\
\hline Ciclismo & $4,5 \%$ & $10,5 \%$ & $6,3 \%$ & $0,0 \%$ & $20,2 \%$ & $11,2 \%$ \\
\hline Ciclovías & $0,0 \%$ & $0,8 \%$ & $1,0 \%$ & $0,0 \%$ & $0,0 \%$ & $0,5 \%$ \\
\hline Disco volador & $0,0 \%$ & $0,0 \%$ & $0,0 \%$ & $0,0 \%$ & $1,0 \%$ & $0,3 \%$ \\
\hline Ecuestre & $0,0 \%$ & $0,0 \%$ & $0,0 \%$ & $0,0 \%$ & $1,0 \%$ & $0,3 \%$ \\
\hline Equitación & $0,0 \%$ & $0,0 \%$ & $0,0 \%$ & $0,0 \%$ & $1,0 \%$ & $0,3 \%$ \\
\hline Escalada & $0,0 \%$ & $0,0 \%$ & $0,0 \%$ & $0,0 \%$ & $1,0 \%$ & $0,3 \%$ \\
\hline deportiva & $54,5 \%$ & $41,4 \%$ & $55,2 \%$ & $75,0 \%$ & $26,9 \%$ & $43,1 \%$ \\
\hline Fútbol & $0,0 \%$ & $0,8 \%$ & $2,1 \%$ & $0,0 \%$ & $0,0 \%$ & $0,8 \%$ \\
\hline Fútbol de salón & $2,3 \%$ & $0,0 \%$ & $0,0 \%$ & $0,0 \%$ & $1,0 \%$ & $0,5 \%$ \\
\hline Gimnasia & $2,3 \%$ & $3,0 \%$ & $2,1 \%$ & $0,0 \%$ & $1,9 \%$ & $2,3 \%$ \\
\hline Golf & $2,3 \%$ & $0,8 \%$ & $1,0 \%$ & $0,0 \%$ & $0,0 \%$ & $0,8 \%$ \\
\hline Halterofilia & $0,0 \%$ & $0,8 \%$ & $0,0 \%$ & $0,0 \%$ & $0,0 \%$ & $0,3 \%$ \\
\hline Hockey Césped & $0,0 \%$ & $0,0 \%$ & $0,0 \%$ & $0,0 \%$ & $1,0 \%$ & $0,3 \%$ \\
\hline Hockey en línea & & & & & \\
\hline
\end{tabular}




\begin{tabular}{|c|l|l|l|l|l|l|}
\hline Judo & $0,0 \%$ & $0,0 \%$ & $1,0 \%$ & $0,0 \%$ & $1,9 \%$ & $0,8 \%$ \\
\hline Lucha & $0,0 \%$ & $0,0 \%$ & $1,0 \%$ & $0,0 \%$ & $0,0 \%$ & $0,3 \%$ \\
\hline Motociclismo & $2,3 \%$ & $0,0 \%$ & $0,0 \%$ & $0,0 \%$ & $0,0 \%$ & $0,3 \%$ \\
\hline Otro & $0,0 \%$ & $0,0 \%$ & $0,0 \%$ & $0,0 \%$ & $1,0 \%$ & $0,3 \%$ \\
\hline $\begin{array}{c}\text { Patinaje de } \\
\text { velocidad y ruta }\end{array}$ & $2,3 \%$ & $0,0 \%$ & $0,0 \%$ & $0,0 \%$ & $1,0 \%$ & $0,5 \%$ \\
\hline Roller & $0,0 \%$ & $0,0 \%$ & $0,0 \%$ & $0,0 \%$ & $1,0 \%$ & $0,3 \%$ \\
\hline $\begin{array}{c}\text { Senderismo/ } \\
\text { caminatas }\end{array}$ & $0,0 \%$ & $0,8 \%$ & $0,0 \%$ & $0,0 \%$ & $1,0 \%$ & $0,5 \%$ \\
\hline Skate & $0,0 \%$ & $0,0 \%$ & $0,0 \%$ & $0,0 \%$ & $1,0 \%$ & $0,3 \%$ \\
\hline Subacuáticos & $0,0 \%$ & $0,0 \%$ & $0,0 \%$ & $0,0 \%$ & $1,0 \%$ & $0,3 \%$ \\
\hline Taekwondo & $0,0 \%$ & $0,8 \%$ & $0,0 \%$ & $0,0 \%$ & $0,0 \%$ & $0,3 \%$ \\
\hline Tenis & $13,6 \%$ & $17,3 \%$ & $15,6 \%$ & $12,5 \%$ & $9,6 \%$ & $14,3 \%$ \\
\hline Tenis paraolimpico & $0,0 \%$ & $1,5 \%$ & $0,0 \%$ & $0,0 \%$ & $0,0 \%$ & $0,5 \%$ \\
\hline Tiro con arco & $0,0 \%$ & $0,8 \%$ & $0,0 \%$ & $0,0 \%$ & $0,0 \%$ & $0,3 \%$ \\
\hline $\begin{array}{c}\text { Tiro } \\
\text { olimpico }\end{array}$ & $0,0 \%$ & $0,0 \%$ & $0,0 \%$ & $0,0 \%$ & $1,0 \%$ & $0,3 \%$ \\
\hline Varios & $4,5 \%$ & $3,8 \%$ & $6,3 \%$ & $0,0 \%$ & $1,9 \%$ & $3,9 \%$ \\
\hline Voleibol & $0,0 \%$ & $0,8 \%$ & $1,0 \%$ & $0,0 \%$ & $0,0 \%$ & $0,5 \%$ \\
\hline $\begin{array}{c}\text { Total } \\
\text { general }\end{array}$ & $100,0 \%$ & $100,0 \%$ & $100,0 \%$ & $100,0 \%$ & $100,0 \%$ & $100,0 \%$ \\
\hline
\end{tabular}

Fuente: elaboración propia. $\mathrm{N}=385$ piezas periodísticas

\subsection{Género de opinión}

El género de opinión en El Espectador se expresa fundamentalmente por medio de columnas $(60,9 \%)$, caricaturas $(9,4 \%)$ y artículos $(7,8 \%)$. Estos últimos se refieren a personas autorizadas que escriben por un momento específico en el periódico, pero no mantienen la regularidad y especificidad de la ubicación en la página que tiene la columna. El editorial se utiliza en un $6,3 \%$ cuando alude a informaciones deportivas sobresalientes, que usualmente son la nota más importante de la primera página. Los lectores manifiestan su opinión sobre la actividad atlética a través de cartas en un $3,1 \%$, y las viñetas se emplean en un 1,6\%.

\section{Gráfico N5. Género de opinión}

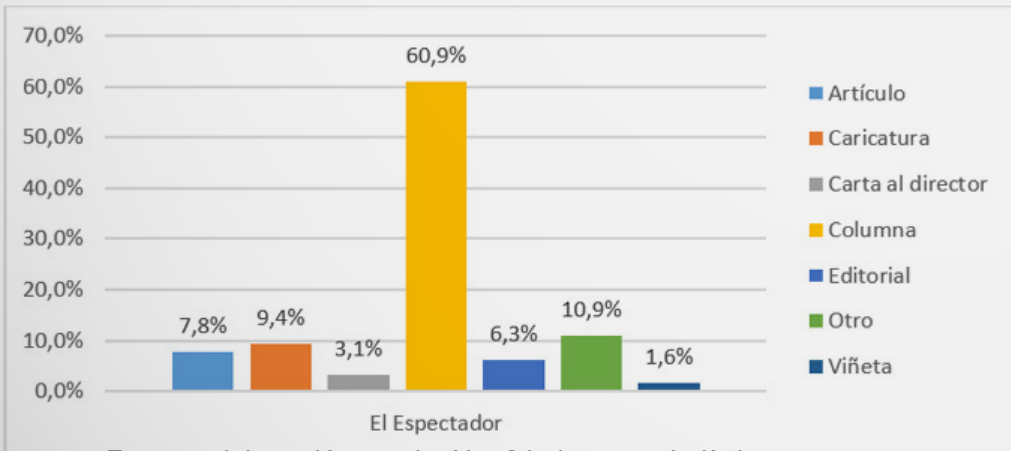

Fuente: elaboración propia. $\mathrm{N}=64$ piezas periodísticas

\subsubsection{Deporte por el que se opina}

De los 40 deportes que se publican en EI Espectador, solo de cinco de ellos se opina, y especialmente del fútbol $(84,4 \%)$. El resto de disciplinas recibe porcentajes muy bajos: ajedrez $(1,6 \%)$, atletismo $(1,6 \%)$, lucha $(1,6 \%)$ y tenis $(3,1 \%)$.

\section{Gráfico N6. Deporte por el que se opina}

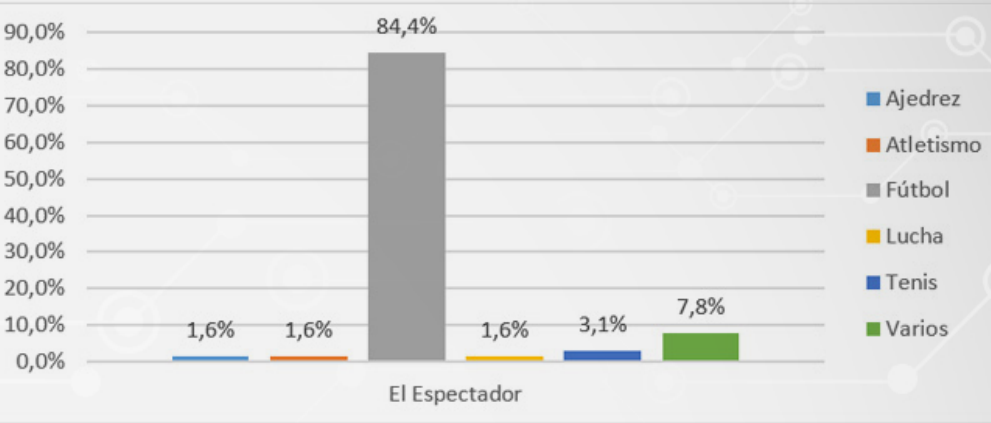

Fuente: elaboración propia. $\mathrm{N}=64$ piezas periodísticas

\subsubsection{Enfoque temático}

El enfoque temático está concentrado en lo competitivo/anecdótico/resultados $(37,5 \%)$ y en menor medida sobre la relación entre el deporte y género $(15,6 \%)$, deporte y política $(14,1 \%)$ y deporte y economía (12,5\%). Otros porcentajes inferiores se muestran en la relación entre el deporte y justicia $(7,8 \%)$ y salud/medicina/psicología $(4,7 \%)$.

Tabla 7. Enfoque temático

\begin{tabular}{|l|l|}
\hline El Espectador & $100,0 \%$ \\
\hline $\begin{array}{l}\text { Competitivo/anecdótico/resul- } \\
\text { tados }\end{array}$ & $37,5 \%$ \\
\hline Deporte y ecología & $1,6 \%$ \\
\hline Deporte y economía & $12,5 \%$ \\
\hline Deporte y educación & $1,6 \%$ \\
\hline Deporte y género & $15,6 \%$ \\
\hline Deporte y justicia & $7,8 \%$ \\
\hline Deporte y política & $14,1 \%$ \\
\hline Deporte y sociología & $3,1 \%$ \\
\hline $\begin{array}{l}\text { Deporte/salud/medicina/psico- } \\
\text { logía }\end{array}$ & $4,7 \%$ \\
\hline Historia del deporte & $1,6 \%$ \\
\hline Total general & $100,0 \%$ \\
\hline
\end{tabular}

Fuente: elaboración propia. $\mathrm{N}=64$ piezas periodísticas 
DNCLUSIONES Y DISCUSIÓN

\section{La comunicación del deporte de manera holística}

En este estudio se encontró que la tendencia del diario es a centrarse en la actividad competitiva $(78,2 \%)$ y no en otros contextos (deporte y educación con el $1,8 \%$, y cultura con el $1,8 \%$, y economía con el $2,8 \%$ ), con lo cual se corre el riesgo de que la actividad agonística sea proclive a convertirse solo en espectáculo que atiende intereses mercantiles (Labio: 163, 264). Esto ocurre en las piezas informativas, pero no así en las de opinión en las que se evidencia una preocupación por contextualizar la actividad atlética con otros enfoques como los del deporte y género $(15,6 \%)$, deporte y política $(14,1 \%)$ y deporte y economía (12,5\%).

A nuestro juicio, cuando en el análisis de contenidos se hallaron enfoques diferentes al estrictamente competitivo y de resultados, el periódico ganaba en diversidad temática y daba a entender que sus periodistas tienen una cultura deportiva amplia, como lo recomienda Bianchi (1991). Ahora bien, es preciso, igualmente, que los periodistas tengan nociones sobre la implicación del deporte con tres áreas fundamentales: con el género, para examinar la forma y frecuencia como se representa el deporte femenino; con la violencia y el racismo, por los problemas de orden público suscitados en algunos eventos deportivos nacionales e internacionales y con la educación (Rojas, 2012).

El manejo de las fuentes. Por un lado, existe un número muy bajo de fuentes consultadas (de los 385 textos codificados, 261 (68\%) no tienen fuentes (muchos de éstos son breves noticiosas) y solo 126 (32\% sí las tienen) y algunas breves, como las de los boletines de prensa, no tienen el crédito respectivo. Vale recalcar que el periodismo deportivo debe tener el mismo valor que cualquier otra especialidad deportiva (económica, cultural, política, entre otras) en lo relacionado con el rigor y la ética (pluralidad y confrontación de fuentes, por ejemplo).

Por otro lado, el $46,9 \%$ de las fuentes corresponden a deportistas y otros porcentajes significativos a entrenadores y exdeportistas. Un aspecto que se ha de resaltar en El Espectador es que en la mayoría de las ocasiones los protagonistas de las piezas periodísticas son los deportistas nacionales con el $73,8 \%$, lo cual demuestra el interés por promocionar los talentos del país. Sin embargo, la consulta de fuentes no se extiende al ámbito gubernamental y federativo. Verbigracia, el gobierno $(3,4 \%)$ y oposición $(0 \%)$, como si no fueran actores importantes en el manejo, confección, desarrollo y fiscalización del modelo deportivo y recreativo colombiano. Igual de sorprendente es que las federaciones solo se citan en un $1,7 \%$.
Explorar otros géneros. Como ya se ha indicado, el género informativo es el que predomina $(41,6 \%$ de breves y $25,7 \%$ de noticias), mientras que otros géneros registran porcentajes menores (crónica, el género más utilizado en la comunicación deportiva, tiene un $9,9 \%$ y la entrevista, un $10 \%$ ). De estos datos se infiere la necesidad de explorar nuevas formas de expresión, para agregar color y profundidad a los contenidos deportivos en el impreso y en las variantes digitales, que son características de medios deportivos de excelencia (Rojas, 2011: 36,98).

Explorar diversas clases de entrevistas, perfiles, con buenos apoyos fotográficos e infográficos, contribuiría a la producción de textos de calidad. En varias oportunidades lo hace El Espectador, como el análisis textual y gráfico del desempeño atlético de la colombiana Caterine Ibargüen, que la hizo merecedora de la medalla de plata en los pasados Juegos Olímpicos de Londres, pieza periodística de calidad publicada en la edición del lunes, 6 de agosto de 2012. En el género de opinión, predomina la columna. No obstante, en la gran mayoría de las ocasiones se opina sobre fútbol $(84,1 \%)$.

Predominio de un periodismo informativo. El Espectador realiza un periodismo "serio", con vocación informativa, que se ve reflejado en sus piezas periodísticas. El calificativo de serio se refiere a que en los contenidos deportivos suele primar la información del desempeño atlético y competitivo, y no los aspectos extradeportivos relacionados con la vida personal y financiera de deportistas, exdeportistas, técnicos, dirigentes, entre otros personajes, como suele ser la tendencia en el periodismo deportivo, inclusive de diarios generalistas en algunos países del mundo como lo señala Labio (2009). De hecho, las piezas se centran en aspectos competitivos (78,2\%), escasamente en contenidos de farándula $(2,6 \%)$ y los titulares que predominan son los informativos $(38,2 \%)$ por encima de los apelativos $(15,8 \%)$ los cuales se utilizan para enfatizar los aspectos sensacionalistas del acontecimiento.

En las observaciones a las piezas analizadas, tampoco encontramos el abuso del lenguaje bélico, errores gramaticales, impropiedades léxicas ni la evaluación minuciosa de aspectos intranscendentes de la actividad agonística (competitiva) que suelen publicarse en otros medios (Garrido, 2009: 48 y Rojas, 2011:36,98). No obstante, se echa de menos un periodismo deportivo más investigativo, de denuncia -como lo pide (Levinsky, 2002: 28,29)- que permita indagar a fondo sobre las situaciones "desviadas" del deporte (corrupción, apuestas, dopaje, malos manejos administrativos de federaciones). El trabajo en equipo con otras secciones es fundamental en estos casos. 
Importancia de los contenidos deportivos para El Espectador. Como señalan Rojas (2011), Billings y sus colegas (2012) y Boyle (2006), los contenidos deportivos son cada vez más demandados en el mundo globalizado, gracias a que tienen la capacidad de atraer la atención de las personas de cualquier clase social, raza, nacionalidad, etc. En El Espectador la importancia que se le da a este tipo de piezas periodísticas es escaso si tenemos en cuenta que un $34,5 \%$ y un $27 \%$ de ellas pertenece a la categoría de bajo y mínimo interés, respectivamente, y solo un $11,4 \%$ corresponde a alto interés. Esto ocurre porque, de acuerdo con la escala de Budd presentada en este trabajo, se utilizan pocos recursos infográficos, no hay presencia destacada de los deportes en la primera página y no hay amplio despliegue (tamaño) de contenidos de este tipo en las páginas interiores, entre otras variables.

Hegemonía de los deportes mayoritarios (hipótesis de investigación, $\mathrm{H}_{\mathrm{i}}$ ). Los datos reafirman que El Espectador sigue la tendencia de "futbolizar la información deportiva" (Rojas, 2011), pese a que este diario informa de 40 deportes (33\% del total) de los 119 que incorporamos a nuestra matriz de codificación, pertenecientes a paraolímpicos, comunitarios, olímpicos y no olímpicos. Sin embargo, la hegemonía del fútbol y, por tanto la poca visibilidad de otras disciplinas minoritarias e, incluso, tradicionales en Colombia como el ciclismo, es evidente en frecuencia de publicación en textos informativos y de opinión, en tamaño, en interés del medio y fuentes consultadas.

Todo ello permite inferir que en el país y el mundo deportivos existen dos realidades paralelas (hipótesis de investigación, $\mathrm{H}_{\mathrm{i}}$ ): por una parte, la del medio de comunicación que enfatiza en contenidos futboleros $y$ en otros relacionados con el automovilismo y el tenis, más representativos de la industria y el mercadeo deportivo y, por otra, la de los éxitos de los atletas colombianos en disciplinas minoritarias como la halterofilia, el bicicrós, taekwondo, entre otras.

Estos datos también nos hacen reflexionar sobre si en alguna medida no se resta calidad a los contenidos deportivos (hipótesis alternativa, $\mathrm{H}_{\mathrm{a}}$ ) al no tener en cuenta criterios como la variedad temática y la pluralidad de fuentes. Es cierto que las limitaciones de espacio, la falta de personal y de tiempo, inciden para que no se cumpla con el periodismo ideal, sin embargo, es necesario pensar en estrategias que atenúen esas debilidades, como, por ejemplo, la reestructuración organizacional de las rutinas periodísticas, un mayor interés de las directivas por los contenidos deportivos y la publicación de contenidos diferenciados en el periódico impreso y en la web.

\section{Bibliografía}

Alcoba, A. (2005). Periodismo deportivo. Madrid: Síntesis.

Angulo, L. (Enero-Junio de 2015). Análisis, en perspectiva, de los contenidos deportivos de Noticias Uno: ¿Un camino hacia la calidad periodística en televisión? Fonseca Journal of Communication(10), 167-202. Recuperado el 19 de septiembre de 2015, de http://goo.gl//7B4kr

Bianchi, F. L. (1991). Deporte y periodismo: el problema de la subvaloración. Recuperado el 08 de 08 de 2014, de Facultad de Comunicaciones. Pontificia Universidad Católica de Chile: http:// comunicaciones.uc.cl/prontus_fcom/site/ artic/20050620/pags/20050620193605.html

Billings, A. C., \& Butterworth, M. L. (2012). Communication and Sport. Surveying the Field. thounsand Oaks, California: Sage Publications, Inc.

Boyle, R. (2006). Sports Journalism: Context and Issues. London: Sage Publications.

Bryman, A. y. (2005). Social Research Methods. Canadá: Oxford.

Budd, R. W. (1964). Attention score: a device for measuring news play. Journalism \& Mass Communication Quarterly, no. 41. pp. 259-262.

Comité Olímpico Colombiano. (12 de octubre de 2015). Sitio web oficial del Comité Olímpico Colombiano. Obtenido de http://www.coc.org.co/ category/ciclo-olimpico/toronto-2015/

Domínguez, J. P. (2006). Ensayo sobre la cuádruple espectacularidad del periodismo deportivo. (c. y. Deporte, Editor) Recuperado el 23 de 09 de 2014, de Revista Razón y Palabra, número 69: http://www.razonypalabra.org.mx/ ENSAYO $\% 20$ SOBRE\%20LA\%20CUADRUPLE\%20 E S P E C TA C U L A R I D A D \% 20 D E L \% 20 PERIODISMO\%20DEPORTIVO.pdf

Garrido, M. (2009). Violencia y sensacionalismo en la comunicación deportiva. En J. M. Montín, Imagen, comunicación y deporte. Una aproximación teórica (págs. 47-77). Madrid: Visión Libros.

Hernández, R., \& Fernández, C. y. (2010). Metodología de la investigación. Quinta edición. Lima, Perú: McGraw Hill. 
Igartua, J. J. (2006). Métodos cuantitativos de investigación en comunicación. Barcelona: Bosch.

La República. (21 de 11 de 2012). Último EGM: El Tiempo es el más leído del país; gratuitos y populares siguen consolidándose. Obtenido de http://nochesdemedia.com/2012/11/21/ultimo-egmel-tiempo-es-el-mas-leido-del-pais-gratuitos-ypopulares-siguen-consolidandose/

Labio, A. (2009). Periodismo deportivo y sensacionalismo. Motivos para la reflexión. En J. M. Montín, Imagen, comunicación y deporte (págs. 161-179). Madrid: Visión Libros.

Levinsky, S. (2002). El deporte de informar. Buenos Aires, Argentina: Paidós.

Mangone, C. (1999). El discurso del periodismo deportivo: entre las filosofías de la vida y la guerra por otros medios. Contratexto, revista de la facultad de Ciencias de la Información, Universidad de Lima, 11-18.

Marrero, O. (2011). Fundamentos del periodismo deportivo. San Juan, Puerto Rico: Terranova.

Rojas, J. L. (2011). Periodismo deportivo de calidad. Propuesta de un modelo de libro de estilo panhispánico para informadores deportivos. Madrid: Fragua.

Rowe, D. (2007). Sports Journalism: Still the 'toy department' of the news media? Communication \& Sports, 8, 385-405.

Semana. (01 de 11 de 2014). Encuesta de líderes I. Obtenido de http://www.semana.com/confidenciales/ articulo/encuesta-de-lideres/407792-3

Vilches, L. (2011). Análisis de contenidos de la agenda informativa. En L. Vilches, La investigación en comunicación (págs. 153-160). Barcelona: Gedisa.

Weerakkody, N. (2009). Research Methods For Media And Communication. Sidney (Australia): Oxford.

Wimmer, R. D. (1996). La investigación científica de los medios de comunicación. Una introducción a sus métodos. Barcelona: Bosch.

\section{Para citar este artículo:}

Ángulo, R. Lizandro y Moreno. C. Antonia (2016). Periodismo deportivo. El fútbol es el Rey. Revista Luciérnaga/ Comunicación , Año 8, N16. Facultad de Comunicación Audiovisual- Politécnico Colombiano Jaime Isaza Cadavid- PCJIC \& Facultad de Ciencias de la Comunicación Universidad Autónoma de San Luis Potosí- UASLP. México. Págs. 10-26.

\section{DOI. 10.33571/revistaluciernaga.v8n16a2}

Link. http://www.politecnicojic.edu.co/images/downloads/publicaciones/ revista-luciernaga/luciernaga-14/ 